Article

\title{
An Institutional Analysis and Reconfiguration Framework for Sustainability Research on Post-Transition Forestry-A Focus on Ukraine
}

\author{
Maria Nijnik ${ }^{1, *(\mathbb{C})}$, Tatiana Kluvánková ${ }^{2}\left(\mathbb{D}\right.$, Mariana Melnykovych ${ }^{3}$, Albert Nijnik ${ }^{4}$, Serhiy Kopiy ${ }^{5}(\mathbb{D}$,

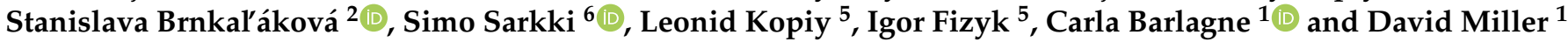

check for updates

Citation: Nijnik, M.; Kluvánková, T.; Melnykovych, M.; Nijnik, A.; Kopiy, S.; Brnkal'áková, S.; Sarkki, S.; Kopiy, L.; Fizyk, I.; Barlagne, C.; et al. An Institutional Analysis and Reconfiguration Framework for Sustainability Research on Post-Transition Forestry-A Focus on Ukraine. Sustainability 2021, 13, 4360. https://doi.org/10.3390/su13084360

Academic Editor: Zuzana Dobsinska

Received: 8 March 2021

Accepted: 8 April 2021

Published: 14 April 2021

Publisher's Note: MDPI stays neutral with regard to jurisdictional claims in published maps and institutional affiliations.

Copyright: () 2021 by the authors Licensee MDPI, Basel, Switzerland. This article is an open access article distributed under the terms and conditions of the Creative Commons Attribution (CC BY) license (https:// creativecommons.org/licenses/by/ $4.0 /)$.
1 The James Hutton Institute, Craigiebuckler, Aberdeen AB15 8QH, UK; carla.barlagne@hutton.ac.uk (C.B.); david.miller@hutton.ac.uk (D.M.)

2 SlovakGlobe, Slovak University of Technology and Slovak Academy of Sciences, Vazovova 5, 81243 Bratislava, Slovakia; tana@cetip.sk (T.K.); brnkalakova@ife.sk (S.B.)

3 Swiss Federal Institute for Forest, Snow and Landscape Research, WSL, Zürcherstrasse 111, 8903 Birmensdorf, Switzerland; mariana.melnykovych@wsl.ch

4 Environmental Network Ltd., Aboyne AB34 5BR, UK; anijnik@yahoo.com

5 Ukrainian National Forestry University, Gen. Chuprynky Str., 103, 79057 Lviv, Ukraine; s.kopiy@email.ua (S.K.); kop.1@i.ua (L.K.); i.v.fizyk@nuwm.edu.ua (I.F.)

6 Cultural Anthropology, University of Oulu, Pentti Kaiteran katu 1, FI-90014 Linnanmaa, Finland; simo.sarkki@oulu.fi

* Correspondence: maria.nijnik@hutton.ac.uk

Abstract: In this paper, we elaborate an Institutional Analysis and Reconfiguration Framework centered around the 'action arena' theoretical approach. We develop this framework to analyze institutional reconfiguration to enhance sustainability, and operationalize it using research methods which focus on documentation of the institutional contexts through an extensive literature review and interviews of experts in forest policy. We apply the Institutional Analysis and Reconfiguration Framework to examine forestry institutions, address forest governance, and investigate their effect on socio-economic and environmental performances in forestry of Ukraine. The paper draws on the state of affairs in post-transition forestry, its difficulties, and new prospects for economic and institutional reforms. We examine challenges and opportunities in forestry and suggest key remedies and prospective ways forward. Results show that a combination of path dependency with the rigidity of institutions and a slow pace of economic and political reforms is the major obstacle to implementing decisions regarding sustainable forest policy. A reconfiguration of social practices is required, as well as the development of capabilities and awareness raising amongst relevant stakeholders, to realize the problems, envision alternative futures, challenge existing institutions, shift power relations and create new norms, rules, and decision-making arrangements. The way towards sustainability in forestry largely goes through changing institutions, and a human dimension of institutional changes reflected in the uptake of social innovation.

Keywords: sustainability; action arena; institutional changes; forest governance; stakeholder engagement; social practices; perceptions; social innovation; transformation

\section{Introduction}

In the 18th century, Hans Carl von Carlowitz published Sylvicultura oeconomica, in which the principle of the 'sustainable use' of forests was discussed for the first time. Today, there are over 300 definitions of sustainability and sustainable development in the academic literature alone [1]. The internationally recognized principles of sustainable forest management (SFM) underpin forest policies and practices in many countries. The concept of sustainable forestry is related to that of SFM but more widely, as both spatially and temporally its relevance is beyond that of forest management [2]. Sustainable forestry 
contributes to improving the well-being of local communities and wider society, and addressing the United Nations (UN) Sustainable Development Goals [3]. Sustainable forestry is a function of natural, man-made, human, and social capital, and the concept incorporates ecological, economic, social (and institutional) dimensions [4,5].

While much has been done to manage forests sustainably, implementing SFM has often led to a shift in emphasis from the productive values of forests and their social and economic benefits to their environmental values and services [6]. In the 2005 assessment of the implementation of the European Union (EU) Forestry Strategy, a concern was expressed over the imbalance in addressing the economic, social, and environmental dimensions of SFM. The report stated that while there has been progress in the environmental aspects of SFM, improvements could be made in the identification of the major economic and social issues to secure sustainable forestry over the short and longer terms [6]. The understanding of the roles of forestry in a bioeconomy emerged as a follow-up, with the bioeconomy seen as a catalyst for systemic change to tackle the social, economic and environmental aspects of sustainability holistically, which is not yet addressed coherently [7].

This observation and meeting the economic criterion of sustainability is deemed to be particularly important in post-transition countries. By a post-transition country, we mean a country that had the former socialist (command-and-control) type of economy but has formally passed its transition c.f., [8] to a market economy by implementing the structural transformations intended: (i) to develop market-based institutions and (ii) to build a new democracy. Such countries have inherited from the previous political and economic systems the mechanisms of decision making that do not take into consideration the present and future conditions for wood production and consumption [2]. For example, in Ukraine, forests have only recently been considered as an economic asset instead of being of State patrimony value [9]. Commercial exploitation of nearly $50 \%$ of forest areas in Ukraine is limited. However, the annual change in growing stock suggests that these forests could produce more timber sustainably. To improve the efficiency of timber production, so that the country could legally export wood [10], significant changes would need to be introduced to forest policy and governance to promote economic sustainability.

The economic criterion of sustainability is important in transition and post-transition countries for the accumulation of financial resources, attracting investment, and enhancing forestry development. Economic and social considerations are interlinked, and the former is critical for resolving societal problems of unemployment, migration, and poverty alleviation, and improving human well-being [2,11,12]. Sustainability in forestry (and especially, when marketable goods and services are concerned) is, to a large degree, associated with the extent to which markets function and enable the delivery of the most appropriate signals while guiding the optimal allocation of various components of capital (including natural capital) in space and time [13].

A specific dimension of the social component of sustainability addressed in this paper is that of institutions, that is the institutions that are to be placed under the obligation to transform the human-environmental interactions in post-transition forestry in Ukraine towards sustainability. Sustainability can be enhanced by rules and regulations and improved by market incentives and/or public policy instruments. In this paper, the rules of the game which shape interactions between policy, markets and civil society are referred as institutions. However, formal institutions may overlook the realities of people [14] and fail to address their challenges. Therefore, in this paper we pay attention to new, or reconfigured societal processes and practices, relationships, networks, interactions, and collaborations between people, including through social innovations [15].

There is a need to better understand institutions and governance in forestry [2]. In this paper, by bringing in conceptual and empirical evidence from Ukraine, our purpose is to fill the knowledge gap associated with the operationalization of institutions and practical implications for changing social practices in forestry of a post-transition country. We achieve this by using the case of forestry in Ukraine as an example. We examine Ukrainian forestry by using the Institutional Analysis and Reconfiguration Framework developed 
and centered around the 'action arena' theoretical approach. The focus is on institutions, the challenges they face, opportunities, trends, impacts, and remedies to problems, and the reconfiguration of social practices for putting forestry on a sustainable pathway. The results show that a combination of path dependency with the rigidity of institutions and a slow pace of economic and political reforms are major obstacles to implementing sustainable forest policy decisions.

\section{Background on Forestry in Ukraine}

Ukraine became an independent state in 1991, and is now one of the largest countries in Europe. It has the 9th largest in Europe forest area of over 10.5 million ha (with 1\% of forestland classified as primary forest; $49 \%$ as other naturally regenerated forest and $50 \%$ - as planted forests). Forests spread across the Carpathian, Polissya (mixed forests), Forest Steppe, Steppe and Crimean forest zones. The proportion of Ukraine's area occupied by forest is approximately $16 \%$, which are primarily concentrated in the Northern and Western regions. The composition of forest species is diverse and varies across the territory c.f., [4]. Coniferous forests (i.e., pines, spruce and fir) occupy $42 \%$ of the forest land, and $43 \%$ is covered with hardwood forests (oak, beech, etc.). The inventory of standing timber volume is 1736.0 million $\mathrm{m}^{3}$; annual wood increment is 35 million $\mathrm{m}^{3}$ and timber harvesting is approximately 20 million $\mathrm{m}^{3}, 85 \%$ of which is clear cutting [16]. Forests are grouped into the following four categories: commercial (37.9\%); protective (32.9\%); recreational (15.3\%); natural reserves, forests used for scientific, historical, and cultural purposes (13.9\%) [17].

Forest land is primarily State owned (87\%) of which $73 \%$ is managed by the State Forest Resource Agency (SFRA). The rest of the State forest land is distributed across several Ministries and Agencies, and 7\% which isnot available for use. Approximately 13\% of forestland is now managed by communal forest enterprises. Forests on this land (belonging in the past to collective farms) are generally depleted and of low productivity $[10,17,18]$.

The core legal act in Ukrainian forestry is the Forest Code (adopted in 1994 and revised in 2006; with additional amendments thereafter). The country passed new laws and regulations in response to the calls for forestry reforms [19], including the State Program of Forests for 2010 to 2015 (which needs to be renewed) and the Strategy for Sustainable Development and Institutional Reform of Forestry for the period through to 2022 [20]. The key challenges, including climate change and sustainability, were identified as priorities in these policy documents. Ukraine also adopted other laws with relevance to forestry, including 'On the Fundamental Principles (Strategy) of State Environmental Policy until 2030 [21]. The Law on Land sale market was approved in the first reading which is a step towards Land Reform though to 2024 although it largely concerns land that is not associated with forestry [22].

The management structure of the forest sector is illustrated in Figure 1. The President has the power to issue decrees directing Cabinet of Ministers to take actions affecting the forest sector. This power has been used in recent years, for example, in relation to a ban on the exporting of round wood [23] and the undertaking of the National Forest Inventory [24]. The Parliament (Verkhovna Rada) and the Cabinet of Ministers have powers to adopt the legislation and approve national programmes on the protection, conservation, use and restoration of forests and the transfer of State-owned forest lands for permanent non-forestry use [10].

The SFRA is the central executive body, the activities of which are directed and coordinated by the Cabinet of Ministers through the Ministry of Environmental Protection and Natural Resources. The Agency implements the State policy on forestry and hunting and is the center of decision-making on forest management and governance. Ukraine's twenty-four regional forestry administrations are subordinate to the SFRA (Figure 1) and have responsibilities for the administrative, legislative and economic supervision of forest management. State forest enterprises are the lowest level in this hierarchy. They are subordinate to their respective regional forestry administrations and plan and conduct 
timber harvesting, sell wood, implement forest management, are responsible for forest regeneration and protection from fires and illegal activities, and so forth.

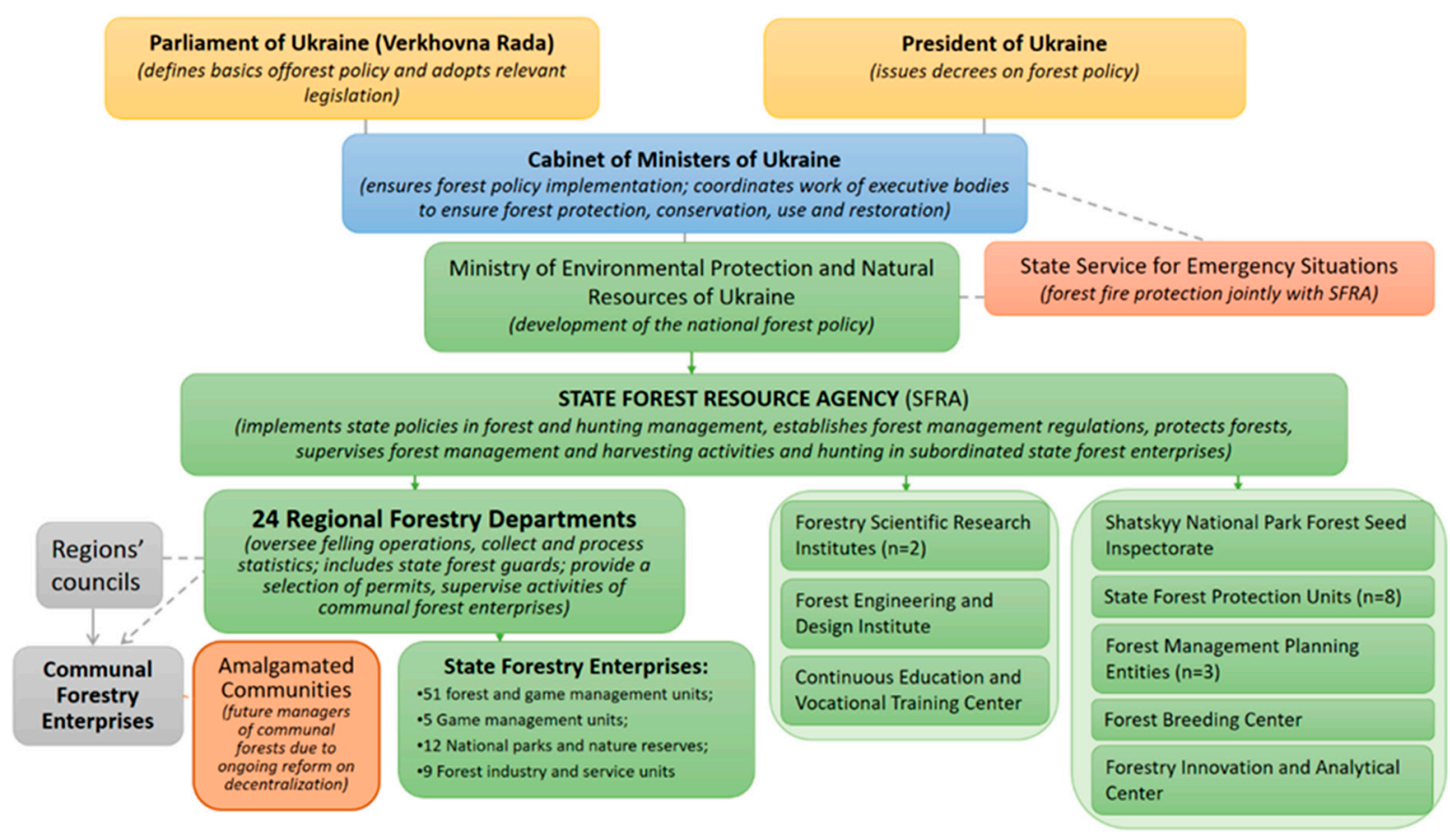

Figure 1. Management structure of Ukraine's forest sector. Source: Adapted from [10,17].

Since Ukraine gained its independence it has started moving from a centrally planned, command-and-control economy to a free market economy (historically, without having enough knowledge and experience of the operation of markets $[4,9,17])$. Forest management is largely based on command-and-control approaches, which were traditional in Ukraine. There is limited influence on decision-making processes by local authorities, small businesses, and local communities [25].

Excessive timber harvesting in the period post World War II was the reason for the decrease in forest cover, with the age distribution of stands skewed towards younger ages. In addition, the uneven distribution of logging activity over the territory threatened forest sustainability. Between 1956 and 1960, timber harvesting was especially intensive in the Carpathian region [26]. More recently, forest vitality has been affected by poor environmental contexts, for example, following the Chernobyl nuclear accident in 1986. Consequently, approximately 3.5 million ha of forests were contaminated; 157,000 ha were taken out of exploitation, while on $43.8 \%$ of the contaminated territory the use of forests has been restricted [17].

When commercial pressures were placed on forests [27], sanitary felling underwent a dramatic rise. In 2016, nearly $47 \%$ of the total timber harvested was through this type of felling operations. That was questioned by international experts [28]. The increase might have suggested either a catastrophic situation regarding the health of the forests or, according to the WWF (2018) report [28], sanitary felling in addition to the permitted annual volume of harvesting was used to hide the over-exploitation of forests. There is evidence that there are bark beetle attacks, and that forests are threatened by extreme events. However, such threats could also be used as excuses for the local state forest enterprises to have the authority to declare a felling as 'sanitary'. Overall, the scale of sanitary felling, along with increased (direct) illegal cutting of timber [29] reduced the endurance of forest stands and contributed to increased soil erosion, and frequent and severe flooding, especially in mountain areas. Forest policy and management focuses on tackling problems, which has led to some positive trends, for example the average age 
of stands has improved; annual tree planting on forest land amounts to 50,000 ha [17]; the area of forests certified according to the Forest Stewardship Council [29] scheme, is 4.5 million ha, and increasing, as is that of designated protected areas (e.g., of nature reserves).

\section{Theory and Methodology}

\subsection{Theories of Institutions}

In the context of sustainability transformation, we reviewed the mainstream theories of institutions. The purpose was to design a theoretical framework for developing an improved understanding of institutions and their dynamics in the forestry of a posttransition country and based on this framework, to analyze institutional perspectives of Ukrainian forestry.

The political theories of institutions primarily focus on the redistribution of wealth and imply that institutions are shaped by a desire of those in power to reassign resources within society. Cultural theories commonly hold beliefs that shape collective actions within current governance arrangements [30]. Economic theories largely suggest that institutions are created whenever the social benefits of creation exceed the cost [31]. Getting the prices right follows logically from 'getting the institutions right'. However, institutions are not always 'right' [32,33]. This has particular relevance to Eastern Europe, where the western market mechanism has been transplanted into the post-regulatory political and economic systems in the absence of proper institutional practices [34,35]. The economic theories of institutions are largely split into neoclassical, classical and new institutional [36].

The ideas of new institutional economists [37-42] and the acceptance of bounded rationality [43] are of importance in the context of this paper. New institutional economics primarily suggests that an optimum can be reached by the use of private bargains through markets, or the allocation of property rights. A focus on minimizing the costs of running a system means consideration of the costs of making transactions and formulating, enforcing, and monitoring contracts [41]. It is accepted that contractual arrangements could rely on robustness of institutions [42] and loyalty, commitment, trust of actors who are considered as social agents.

There are two main approaches to investigating institutional changes from these, new institutional economics, perspectives. The first approach focusses on economic development and considers the system of institutions dependent on the level of economic advance. At a certain stage of societal development, economic development starts exceeding the pace of institutional development. When the gap appears to be too wide, political, and social preconditions for societal transformation arise [2]. The second approach focuses on 'action arenas' $[2,38,40,44-46]$. Within this approach, one way of exploring institutional changes is to consider them as having been caused by the responses of actors to shifts in relative prices and preferences; and a second way explains institutional reconfiguration as caused by conflicting interests. Inefficient institutions exist because of 'path dependency', but new institutions are continuously created [47,48]. Social movements [49] and collective actions [50] are recognized as drivers of institutional changes. They are not always progressive [51], but often promote societal advances.

With this in mind, and to analyze the reconfiguration of social practices c.f., $[2,15,45,46]$ in forestry of a post-transition country, the 'action arena' approach was adapted and applied. Its application was with the understanding that collective action as well as social movements can be a source of constructive changes and a breaker of path dependencies. Also, social innovations can identify new directions and be exemplary elements for institutions to create better pathways towards desired outcomes [2].

\subsection{An Institutional Analysis and Reconfiguration Framework}

The Institutional Analysis and Reconfiguration Framework (IARF) used for understanding and operationalizing social practices, and their key elements, interrelationships, and dynamics, is illustrated in Figure 2. It was informed by a review of the literature on 
institutions and their changes, tested with and validated by Ukrainian forestry experts. For simplicity, in Figure 2, we omit inter-links between the socio-ecological (resource) [46] and institutional systems [52], limiting our observations to the latter. That is where the interactions take place amongst the actors who represent a variety of stakeholders in the action arena of forestry.

Institutions are the conventions, norms and rules which provide stability, and coordination, regularize life, produce and protect human values and interests [53]. Institutions shape the patterns of political, economic, and social interactions [47]. They define behaviors [32], structure interactions [54] and share understandings of what should and should not be done [55].

An institutional environment is the rules-in-use [37], specified in written regimes (i.e., formal rules) [56], and manifested in unwritten conventions and codes of conduct (i.e., informal rules shared by people for example, within a profession, or a region). The strictly stated formal rules are of policy and economy (e.g., laws, strategies, regulations, property rights), and administrative orders, rules and instructions. Informal rules comprise value judgements (e.g., attitudes, perceptions, preferences, conventions, customs, traditions, morals) and are largely self-enforcing.

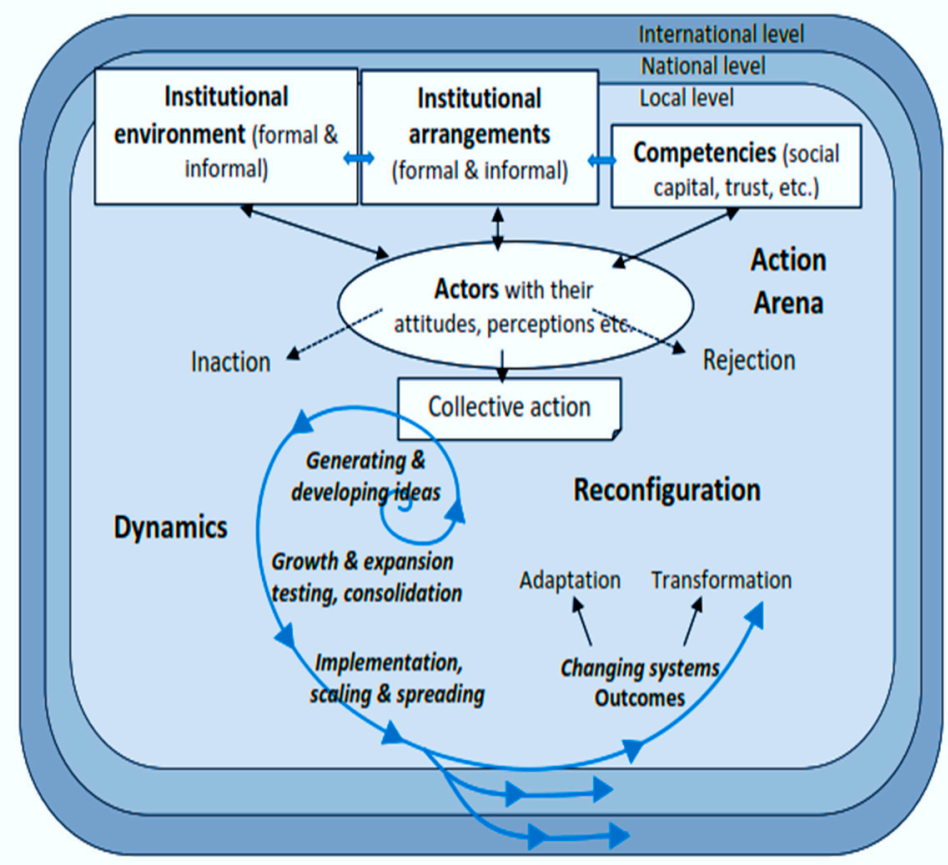

Figure 2. Institutional Analysis and Reconfiguration Framework. Source: Authors' elaboration based on $[4,46,57]$.

Institutional arrangements, formal (governance structures) and informal, are the mechanisms for co-ordination of societal interactions within the institutional environment. The institutional environment consists of the broader socio-economic framework within which different interactions amongst actors take place. The arrangements (the results of their analysis are presented in Section 4.2, following presentation of the findings of the analysis of the institutional environment in Ukrainian forestry) can be based on markets, authority, collective actions, or take hybrid forms $[4,58]$. Markets constitute governance by voluntary exchanges between parties. Hierarchy is governance by command-and-control instruments, when authority is assigned to actors, on the basis of top-down approaches. Collective action is a co-ordination by common interest when people act together [58].

The reconfigured institutions (i.e., new-if the reconfiguration results in transformation, or modified-via their adaptation) (Figure 2) evolve from those which are preexisting [59]. To enhance the reconfiguration, the characteristics of the physical world and 
'rules-in-use' require to be modified [37]. When the rules-in-use are changing, particular attention should be paid to competencies and capabilities of relevant actors $[2,60]$. Figure 2 indicates that actors (with their knowledge) are at the center of institutional reconfiguration. They have their attitudes, preferences, and beliefs, information-processing capabilities, and selection criteria. They interact, learn, and make decisions on the allocations of power and resources, set up agencies and distribute responsibilities through and within existing institutions, or by establishing new ones.

Actors (see Section 4.3 for the results of the analysis of the Ukraine's forest sector) face different decision-making situations within the institutional setting, including designing civil society initiatives and developing social innovations [2]. The competencies of actors (i.e., technical, cognitive, motivational, organizational, and communicational) which include social learning, experience, participation, communication, reciprocity, motivation, commitment, and trust, are important for the reconfiguration [46]. Capability development leads to changes in the belief systems and cultural precepts [61], while the knowledge developed and conveyed within the action arena and externally provides actors with operational efficiency and flexibility [2].

The concepts of institutional transformation $[33,36]$, transitions $[4,62,63]$ and social innovation $[15,46,64]$ address societal changes and offer solutions to challenges faced by forests and the communities which depend upon them [15]. The concepts imply that innovative social practices need to be operated by actors having the capacities to value knowledge, and assimilate, advance, and apply it, as appropriate [65]. The building of trust is especially important where social capital mechanisms have been eroded by regulatory institutions and grey networks (e.g., as in some post-transition countries) as trust promotes co-operation and leads to improved institutional performance [66].

The complexity and interdependencies in the action area (Figure 2) also imply that the reconfiguration of social practices cannot be explained exclusively by the inner logic of Ukrainian forestry, but also requires consideration of the interactions between politiconormative, socio-ecological and socio-economic contexts [46]. These contexts are complex and dynamic, and intricately intertwined with a range of dimensions that foster or hinder institutional changes and shape their trajectories. The entire cycle of a spiral model (lower part of Figure 2) implies that institutional changes start from ideas, develop to prototyping and piloting, and proceed to implementation $[57,67]$. Eventually, it could result in novel arrangements and regimes $[33,68]$ and through their scaling up and/or out, could spread [69], leading either to adaptation or to transformation of the system.

\subsection{Using the Framework to Examine the Reconfiguration}

We applied the IARF to analyze institutions in a post-transition country and investigate their effect on economic and environmental performance in the forest sector. The research involved system analysis based on the principles of scientific cognition and objectivity, through which we established logical structural relationships between the elements under investigation, as well as process analysis. Primary data were collected through interviews and empirical evidence obtained from the analysis and synthesis of the information derived from various sources of reporting and a survey of literature, Table 1. A holistic picture was formed of the reconfiguration of social practices and produce results, based on a set of elements under investigation and their interactions. An institutional analysis was carried out to identify causal relationships illustrated in Figure 2, and theoretical analysis and synthesis based on the concepts of new institutional economics. The use of general scientific methods of formal logic was conditioned by the need to investigate the mechanisms of development of institutional changes, and to distinguish factors that reinforce path dependencies, the rigidity of institutions, persistent governance failures and other contexts that hinder sustainable development of Ukrainian forestry. 
Table 1. Summary on data collection.

\begin{tabular}{|c|c|c|}
\hline Activity & Focus or/and Objective & $\begin{array}{c}\text { Number of Participants or Analysed } \\
\text { Literature Sources }\end{array}$ \\
\hline Forest policy document analysis & $\begin{array}{l}\text { All forest related laws and regulations and } \\
\text { forest policy modifications in Ukraine have } \\
\text { been analysed }\end{array}$ & $\begin{array}{l}\text { All forest policy related laws and } \\
\text { regulations published after 2000, as well } \\
\text { as recently developed policy drafts } \\
\text { currently under public consultations }\end{array}$ \\
\hline $\begin{array}{l}\text { A survey of peer-reviewed } \\
\text { publications extracted from the } \\
\text { Scopus data base }\end{array}$ & $\begin{array}{l}\text { Publications on governance, institutions, forest } \\
\text { policy and management associated with (post-) } \\
\text { transition countries, with the main focus on } \\
\text { Ukraine, published in peer-reviewed } \\
\text { scientific journals }\end{array}$ & $\mathrm{n}=45$ \\
\hline $\begin{array}{l}\text { Review of reports of international } \\
\text { organizations and programmes }\end{array}$ & $\begin{array}{l}\text { A synthesis study of findings from relevant EU } \\
\text { projects and those conducted in Ukraine and } \\
\text { relating to key challenges in the forest sector. }\end{array}$ & $\begin{array}{l}\mathrm{n}=12 \text {, including reports of the EC, EU } \\
\text { ENPI_FLEG, FAO, IUFRO, IUCN, World } \\
\text { Bank and WWF }\end{array}$ \\
\hline $\begin{array}{l}\text { Review of recent publications in } \\
\text { national language and "grey } \\
\text { literature" information }\end{array}$ & $\begin{array}{l}\text { Collection of relevant recent discussion points } \\
\text { on forest policy reforms in Ukraine from the } \\
\text { perspective of different stakeholders }\end{array}$ & $\begin{array}{l}15 \text { publications, internet search and } \\
\text { media releases of relevant organisations } \\
\text { (e.g., SFRA), NGOs, community groups, } \\
\text { and media platforms }\end{array}$ \\
\hline $\begin{array}{l}\text { Interviews of forestry experts } \\
\text { from Ukraine }\end{array}$ & $\begin{array}{l}\text { The survey and associated questionnaire were } \\
\text { designed to develop a better understanding of } \\
\text { causality, design, performance, and impact of the } \\
\text { reconfiguration of social practices (Nijnik et al. } \\
2020 \text { ) }\end{array}$ & $\begin{array}{l}\mathrm{n}=13 \text {, including: (i) forest policy actors } \\
\text { at the national level }(\mathrm{n}=2) \text {; (ii) forest } \\
\text { scientists at levels from local to national } \\
(\mathrm{n}=3) \text {; (iii) forest decision makers at the } \\
\text { regional level (mountain, Western part of } \\
\text { Ukraine, and its lowlands part, } \mathrm{n}=2) ;(\mathrm{iv}) \\
\text { forest managers at the local level }(\mathrm{n}=2) ; \\
\text { (v) representatives of communities of } \\
\text { practice: NGO }(\mathrm{n}=2) \text { and local } \\
\text { communities }(\mathrm{n}=2)\end{array}$ \\
\hline
\end{tabular}

The systematic survey of peer-reviewed publications was performed (in English) using the Scopus database, which is multidisciplinary and the one of the largest databases of scientific literature [70]. The search terms were chosen based on the conceptualization depicted in Figure 2, and used in searches which aimed to identify relevant entries published since 1991, when the transition to a market economy and a new democracy started. Key steps of the survey are illustrated in Figure 3.

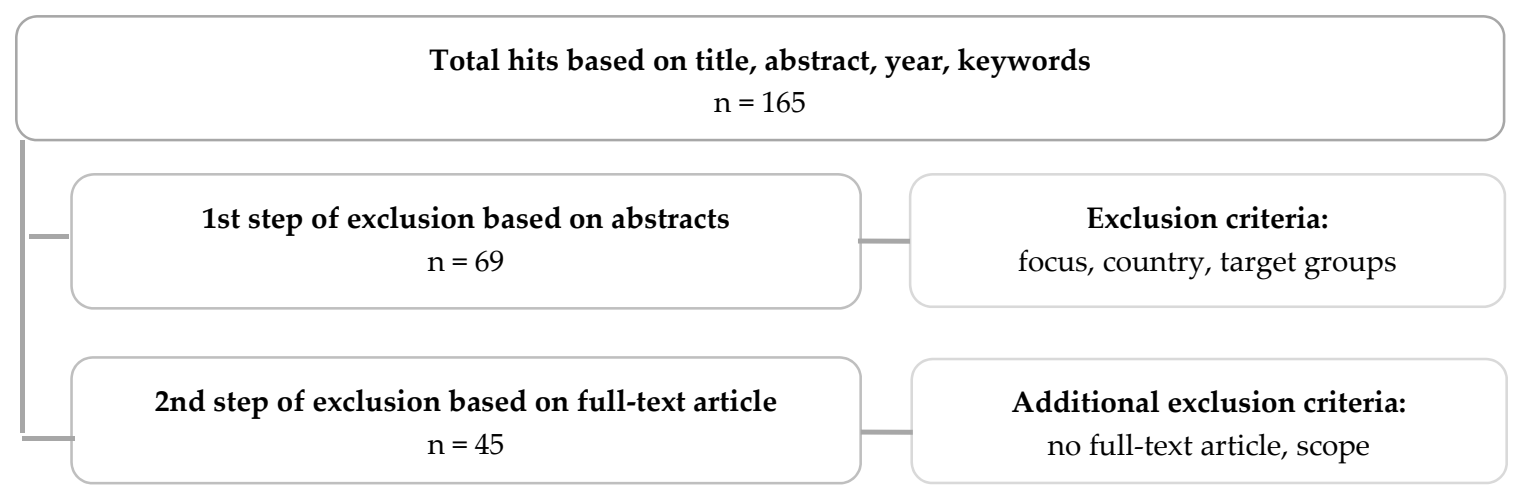

Figure 3. Key steps in the survey of peer-reviewed publications found in the Scopus data base. Source: Authors' elaboration c.f., [71].

A descriptive analysis was undertaken of the abstracts of the studies identified. This identified a set of publications for which the full texts were reviewed of the most relevant articles and coded the respective sections. During coding we observed that some studies 
covered a wide range of different, but often overlapping, topics that relate to institutions and their changes in Ukrainian forestry. When the detailed information was collected, an in-depth qualitative analysis of the peer reviewed publications identified, was conducted.

A survey of the opinions of experts was based on semi-structured interviews about the essence of and interrelationships amongst the institutional elements demonstrated in Figure 2, and on problems and challenges facing Ukrainian forestry, prospective solutions, and opportunities for the future (i.e., along the reconfiguration path, illustrated in Figure 2). The questionnaire was translated into Ukrainian, and after the interviews all of the answers were translated into English and subject to a discourse analysis. This mixed methods approach enabled the corroboration of findings through triangulation. It also ensured that these findings were grounded in the experiences of the interviewees.

\section{Results and Discussion}

\subsection{Institutional Environment}

The results show that, generally, pro-environmental legislation may not result in sustainable forestry, amongst the reasons for which is a mismatch between sustainability concerns and forestry institutions. Forest enterprises and entrepreneurs are guided primarily by considerations of economic efficiency and profitability [72]. Due to market changes, economic and financial considerations are becoming crucial for decision-makers [4]. Therefore, despite the official norms for the sustainable use and protection of forests, and given the inadequate prices and fiscal policies [73], forest practitioners seek to cut trees and sell timber. Although ecological and environmental objectives are present in Ukrainian policies (i.e., in the institutional environment, Figure 2) associated with forests, commonly these rules and regulations contradict the requirements of forestry practices, unintentionally encouraging the development of shadow systems.

To alleviate this negative phenomenon, in 2005, the ban on exports of sawn wood (of ten tree species) was introduced by the Ukrainian Parliament [74]. To stop unregulated timber cutting, and to support the domestic wood processing industry, in 2015, a law was adopted [23,74] which introduced a 10-year moratorium on the export of round wood (industrial, unprocessed timber, rough logs), limiting Ukraine's export of energy wood only [75]. However, for the reasons above, the compliance with regulations is difficult to ensure $[12,76,77]$, a problem compounded by inadequate monitoring and enforcement mechanisms due to financial difficulties and other barriers to implementation [78]. So, illegal timber logging in Ukraine continues [33,79], and some of that timber transported to foreign markets [80]. A positive change was that the Ukrainian Government developed regulations to strengthen the monitoring of forest harvesting and, starting from 2019, forest users are required to use the State electronic timber accounting system for entering information on timber harvesting and sales. Since February 2020, forest enterprises with an annual net income of more than USD340,000 have been obliged to sell all their timber through the electronic auction system [10,81].

Enhancing timber production is important. However, it has to be accompanied by appropriate monitoring systems that ensure the legitimacy of the operations, and accuracy of the reporting. A further requirement is the understanding that economic rents are a measure of wealth, and the proportion of quasi-rent collected by governments indicates whether the revenue from forestry is sustainable [82]. However, in post-transition countries, forest resources are commonly undervalued, information is asymmetric, fiscal and tax policies are inadequate [73], and there is a wide discrepancy between the costs of production and prices for timber (e.g., on world markets) $[33,83]$. Under these conditions, rent seekers tend to sell wood and redistribute wealth according to their interests. These interests may do nothing to enhance the efficiency or promote innovation in the forest sector.

Therefore, while pro-environmental laws and rules formally govern $[19,81]$ they fail to deliver what they aim to achieve $[33,84]$. Consequently, in the six years to 2017 , losses caused by illegal logging are believed to have increased by $77 \%$ [11]. Some estimates suggest that in 2019 the volume of illegal logging in State forests reached 118,000 $\mathrm{m}^{3}$, causing 
approximately 27 million Euros of damage [17]. National and international experts have reported that illegal logging puts at risk Ukraine's reputation [79,83]. The Earthsight [80] reports how timber in Ukraine goes to shadow sawmills (approximately 12,000), and then predominantly exported.

With proper institutions, timber exporting can be beneficial for the economy through decreasing the budget deficit and providing resources to invest in modernizing machinery and promoting innovation. However, such benefits may not accrue in post-transition economies. Our findings indicate that despite the efforts made, the current institutions permit a shadow economy to persist. Theoretically, this leads to a reduction in the tax base of the State and its official foreign exchange holdings, worsening the economic performance [85] and, without having sufficient resources, limiting any scope for providing financial incentives for supporting sustainable development of Ukraine's forest sector. Therefore, in a post-transition country, with its weakened institutions, and prices that do not reflect the real value of forest resources and their scarcity [33], it is even more important (but more difficult) to employ economic indicators of sustainability.

In theory, for sustainability to be consistent with economic efficiency the growth rate of the forest must be greater or equal to the interest rate [4]. Maximizing the net present value (NPV) of forests involves a comparison of the net benefits from postponing harvesting with the net benefits from harvesting timber and investing the profits. However, the objective of maximizing the NPV from forests with moderate growth often promotes higher harvest levels than the net growth of forest stands. Therefore, focusing on economic efficiency alone encourages the establishment of fast-growing commercial plantations [9]. This, in turn, endangers biological diversity and the health and vitality of forests [26]. The establishment of monoculture plantations often increases the costs associated with the care and protection of forest stands that are less stable biologically; and these costs are not always accounted for [4]. Thus, in post-transition economies where there are acute market failures (e.g., non-internalized externalities) multiple ecosystem services often remain undervalued [33], and some social benefits of forests undermined.

Implementation deficits (common to young democracies) demonstrate a gap between the formulation of sustainable forest policy goals and putting them into practice [13,84]. The ban on timber exports is another example of what can happen when a law that was intended to enhance the protection and sustainable use of forests in practical terms leads to adverse economic consequences. The ban on round wood export raised concerns amongst the public, NGOs, mass-media [75] and EU officials [86]. The gap between the formal rules of institutional environment and the arrangements, and those which are informal in nature (Figure 2) has increased since the start of the 'transition' in the late 1990s $[4,87]$. The vertical mismatches detected amongst national, regional, and local policies, and between their goals and the situation on the ground, and the horizontal mismatches, due to a lack of policy co-ordination across sectors [76], have contributed to creating institutional challenges $[25,88]$.

The experts interviewed reported that laws and regulations that generally govern the forest sector are not fit for purpose. They explained that: (i) even the most recent laws and regulations do not have the institutional mechanisms necessary for the enhancement of sustainability in forestry; (ii) there are no, or limited, policy instruments to support community participation and social innovation; (iii) there has been a low emphasis on securing tenure rights in forestry (beyond the public forests); (iv) there are no explicit relationships between forest authorities and contracts or markets in the main forest law. Findings highlighted the need for a new package of rules and regulatory acts and norms, preferably co-developed by forest policy actors, jointly with scientists and practitioners (e.g., experts in bioeconomy, entrepreneurship, climate change adaptation, and social innovation) and underpinned by traditional knowledge of people on the ground.

Progress has been made in the development of a new package of rules and regulations relevant to forestry. Notable amongst these are: the Decree on Additional Actions regarding the Development of the Forest Sector, Wise Nature Management, and the Maintaining 
of Objects of the Nature Protection Fund [89]; the Decree of the President of Ukraine On Measures for the Conservation of Forests and the Rational Use of Forest Resources [81]; the Strategy for Sustainable Development and Institutional Reform of Forestry for the period through to 2022 approved by the Cabinet of Ministers [20]; and a draft of the State Strategy on Forest Governance until 2035 put out to public consultation [90]. The experts interviewed recognized the positive nature of this document being put out to public discussion.

The legislative acts and norms that should guide the advancement of the forest sector in the short and medium terms, and in future, require the support of stakeholder groups. However, such groups have highly diverse perceptions of what is required [2]. Moreover, the aspirations of forest policy are often not realizable due to a lack of suitable supporting instruments (i.e., legislative, economic, agreement, information, communication and knowledge-based), for use at different levels of governance. A key gap is the provision of financial instruments and incentives (of improved price and fiscal policies) for directing forestry towards its more sustainable development.

The experts interviewed admitted that to succeed in transitions towards sustainability: (i) forest policy should be more open and adaptable to make it possible to incorporate innovative decisions or involve new actors, under changing conditions; (ii) policy documents should be specific and clearly presented to end-users; (iii) there should be consultation with relevant stakeholders prior to decisions being taken; (iv) horizontal tuning of forestry plans should be encouraged (e.g., aligned to with physical planning and nature conservation); (v) vertical tuning should align the executive structure of institutions with the policy structures, and ensure that greater rights and responsibilities, as well as resources (including financial), are devolved to lower level forestry units; (vi) the practicalities of policy and management plans, concerning targets, tasks and resources must be improved.

The findings show that there is a lack of harmonization between policies relating to forestry in Ukraine, and with national and international regulations on environmental and natural resource use. The interviewees stressed the importance of developing an interlinked long-term Strategy, a Programme and specific plans of actions that could enhance sustainable forestry development. A set of such policy documents should be consistent with relevant international treaties and aspirations of different social groups in Ukraine and be in the context of drivers such as a changing climate.

Overall, our results indicate that the current institutional environment is improving but still is not fit for purpose. The experts stressed that forestry regulations are often "too vague", and that the "price-forming and fiscal policy, and tax system need to be urgently improved". The interviewees also reported that regulations change frequently, there is a lack of transparency and that the legislation is often misleading and contradictory, resulting in legislative and bureaucratic confusion, and institutional redundancy $[33,76]$. In combination, this set of issues make forest policy and management rules difficult to follow and implement. Thus, they remain open to arbitrary decisions, leaving room for corruption.

\subsection{Institutional Arrangements, Governance, and Competencies}

In part, the governance misfit observed can be explained by the grabbing hand model [31] in which the institutional incentive to address economic efficiency is displaced by the aim of wealth redistribution. This occurs when politicians and bureaucrats, focusing on the particular interests of groups in politics, and desires to retain power, follow impulses to redirect wealth to themselves. Their actions hinder economic growth, lead to social distortions and marginalization, and restrict political and economic freedom [33].

'Patrimonialism' is the phenomenon when the State or politicians consider themselves the ruler and proprietor of the country [91]. This phenomenon brings together economics and politics, resulting in the so-called politonomy [33]. The most destructive phenomenon is the criminal-political nexus, an alliance amongst oligarchs, members of the law enforcement and security agencies, and gangs of organized criminals who tend to undermine pro-market reforms and appropriate resources [92]. While neopatrimonialism, crony capitalism and 
kleptocratic practices were not apparent in Eastern Europe prior to the end of the 1990s, with regards to the fate of forests, the 'grabbing hand model' of governance [31] has been evident in Ukraine since then and with significant adverse effects on the forest sector $[2,33]$.

There has been a continuity of institutions based on a hierarchy [9], and processes of transformation face significant challenges [50]. The national government announced steps to put forestry on a pathway to sustainability. However, our findings show it is difficult to reconfigure social practices in forestry in the country with an inopportune and unstable socio-economic situation that creates preconditions for social tensions and conflicts $[89,93]$. An additional difficulty lies in the poor level of well-being of forest-dependent communities comprising people who tend to make their income out of timber [78]. As stated by one interviewed expert, at times this leads to conflicts between community members and forest guards. Furthermore, the decline in living standards in recent decades has increased the reliance of local people on non-wood forest products (NWFP), in some localities leading to overharvesting of NWFP [94].

In these conditions, as stressed by other authors [12,18] and supported by the experts interviewed, forestry reforms should seek to properly integrate economic liberalization in the sector with the public interests in the sustainable use of forest multiple ecosystem services $[95,96]$. Targeting sustainability would require the adjustment of the institutional arrangements to align a market economy and a new democracy $[13,93]$. The institutional reconfiguration suggested entails democratization and participation; economic liberalization and (controlled and confined) privatization; political, administrative, and fiscal decentralization; and restructuring of government c.f., $[58,97]$. However, according to the experts interviewed, supported by our findings from the literature, "that Ukrainian forests largely remain public is right, as this has saved these forests from destruction" [12,97].

The experts interviewed reported that the current formal model of the distribution of tasks and resources (including financial) in Ukrainian forestry, between central and regional (and local) authorities, and amongst forest management structures, neither reflects nor meets the requirements of foresters, other social groups, and society in general. At the lowest level within the system of State forest management (Figure 3), there are numerous State forest enterprises that are supposed to operate on the principles of self-financing [10]. The principal functions of the enterprises are tree planting, silvicultural practices, and timber supply. However, the list of activities differs across and between regions and depends on the availability of resources and production capacities, and often also on 'personal relationships' and on 'prestige amongst the staff and local authorities' [4,33,97].

In 1996, forestry and the forest (wood processing) industry were separated [85]. The rationale of the split and its positive and negative effects have been analyzed, for example in [33]. However, many forest enterprises experience financial shortages and are vulnerable to conflicts of interest [10]. Largely, this is due to the current emphasis on their selfsufficiency without an adequate supporting fiscal policy or approach to forest taxation [73]. This point was stressed by the experts interviewed, who suggested "improving forest taxation, giving more rights and responsibilities to local/regional level forestry authorities, and encouraging the development of various partnerships" (e.g., private-public).

They also identified the need for actions to target sustainability to be coordinated horizontally (e.g., between regions), and vertically (i.e., across local, regional and national levels). They agreed on the need for: (i) a systems approach to institutional arrangements, with a consideration of interdependencies and in which each forest is considered as a subsystem of a higher unit in the system, and Ukrainian forestry is considered to be a subsystem of European and global forestry; (ii) comprehensiveness, i.e., that various factors of forestry development (e.g., economic, social, environmental) are taken into account (where possible) at local, regional and national levels, and underpinned by sustainable 'human-environment' interrelationships; (iii) objective principles, meaning that the priority objectives for each level of forestry development (starting from enterprises and through to the forest sector) should be identified and targeted. 
However, the results show that rules-in-use by forest governance in Ukraine (i.e., institutional environment, Figure 2) correspond to government laws; institutional arrangements are built into the governmental structure, and the entire system of institutions does not maximize gains for the participants [9]. The importance of 'good governance' [12], for sustainable management of forests is increasingly emphasized in international standards, together with the need to develop and apply integrated approaches in policy formulation and implementation with wide public participation [6]. This implies that a restructuring of forest governance is necessary in Ukraine. However, such restructuring will be difficult because the issues associated with 'path dependency' [47,48] are exacerbated by insufficient stakeholder capabilities to implement societal transformation $[2,98]$.

\subsection{Actors in the Action Arena}

The failure of governance, relating to both formal and informal institutions (Figure 2), is inter-linked with the low level of development of social capital and competencies [2]. The role of people (civil society actors, forest relevant stakeholders, communities of practice [99], with their knowledge and capabilities) is crucial for institutional reconfiguration [46]. The role of competent and inspiring leaders is also very important [100]. Institutional changes proceed together with changes in individuals, and vice versa [101]. However, capabilities to change and socially innovate are personified in codes of human behavior (underpinned by attitudes, perceptions, and competencies), which are often more resistant to change than other elements of institutions. These are path dependencies justified by a cost of change and in the sense that for the creation of a new order there must be evidence that it will be more desirable to people than the old one [47]. Thus, the reconfiguration of social practices can be more complicated than re-organizing or establishing new agencies [34].

The challenges towards sustainability include a lack of vision of the ultimate goal of reforms; tolerance of corruption; the 'established' practice of quota-based appointments (from political parties) of managers who may have insufficient knowledge and/or management capabilities [18]. The experts interviewed stressed: (i) a low level of motivation of policy actors; (ii) a shortage of skilled specialists (e.g., trained to make decisions about markets and entrepreneurship), including in senior management positions; (iii) misperceptions of forest policy targets, measures and instruments by local stakeholders, likely to be due to the shortage of information and conflicting interests [102]; iv) a lack of resources by forest enterprises, on the ground, especially financial; $v$ ) deficiencies in information systems (i.e., not meeting modern requirements [103]); (vi) weak democratic institutions and processes of participation [104]. Continuity and rigidity of political and economic institutions were reported, with a consequence that the governance of forests often results in conflicts instead of cooperation and partnerships [50].

Ukraine's employees have comparatively low salaries, and some officials in controlling services are open to bribery [95]. Sometimes, officials at a higher-level take advantage of their positions with the support of high and inappropriate taxes (as indicated by our interviewees). The forest tax legislation, which has severe adverse impacts on forestry units [73] also creates incentives for enterprises to financially compromise officials rather than pay high taxes [4]. Therefore, many businesses either struggle to survive or tend to pay significant amounts in bribes or seek to hide their operations [33]. Corruption and 'black markets' can be observed in some forest enterprises involved in timber harvesting, some private companies dealing with wood-processing, and some forest agencies [83]. The presence of 'black' and 'grey' timber markets (i.e., with different degrees of tax avoidance) implies that the institutional environment is inconsistent with sustainable forestry development [13], potentially reducing the delivery of forest ecosystem services and reflecting the difficulties currently encountered by the sector.

Thus, the transformation process slows down because of the unfavorable institutional environment, failures in governance [50] and because of historically low levels of communication and reciprocity amongst actors, inadequate competences to initiate and develop changes, and their low motivation, commitment and levels of trust [54,105]. One of our 
experts admitted that "most effectively forestry can be led by knowledgeable politicians, who have worked in forestry, who love forests and the sector and want to help it to function better". Therefore, forestry reform is needed to build the human and social capitals, develop capabilities, and direct motivations of policy actors towards supporting a market economy and a new democracy, with more active involvement of civil society in the decision-making processes [14].

The interviewees identified an urgent need for relevant stakeholders (e.g., local communities) to be engaged in the plans and management of forestry, reflecting the increasing importance of the role of forest non-marketed (public) goods and services. Wider end-user engagement (e.g., through public consultations, participatory forums, by co-construction of knowledge) should be a central feature of the reconfiguration of institutions in the sector. Moreover, forestry is linked to other land-uses, so the economic, social, and environmental dimensions of forest policy must dovetail with other (short and long-term) societal interests to better fit into and underpin the strategy of sustainable development.

\subsection{Further Sustainability Considerations}

Our research has added evidence to the observation that not all forest stakeholders perceive that Ukrainian forests need more protection or that illegal logging is a critical issue [102]. As noted by one of our experts: "A negative and wrong image has been created by "populists', giving the impression as if Ukrainian foresters mine forests". Therefore, it is important to see illegal logging as being a consequence of institutional (e.g., policy, governance and market) failures, not only as a cause of unsustainability in the forest sector c.f., [80,83]. Illegal logging, a shadow economy, and corruption all benefit selected groups at the expense of society and forestry; tax avoidance increases the budget deficit, and taken together these and other factors create conditions in which the State becomes unable to support forestry and protect the environment. It is a vicious cycle, which is a cause of stagnation and path dependencies in post-transition forestry [106].

An important and obvious consequence of illegal logging is of fewer financial resources flowing to the State budget (due to tax avoidance). A possible decrease in the overall scale of timber harvesting (i.e., at the expense of a lower level of forestry activities, including legally harvested timber) could then be anticipated. This could lead to either less (because of the high scale of illegal logging) or more natural assets being protected (due to the decrease in legal timber cut) for the benefit of future generations. Better understanding is required of these trade-offs, including those, associated with changes in regulations.

For example, if regulations become less 'pro-environmental', and make it easier for more legal timber harvesting, would that lead to better or worse protection for natural assets? The answer to what is societally more desirable depends on the goal. Such a goal could be to protect natural assets from mining and preserve them for future generations, or eliminate illegal logging and make the economy more functional (e.g., by making all timber cut legal by changing the regulations)? Hypothetically, if all logging becomes legal, more money will go to a national budget and can be used in part to support forestry. However, the situation would depend on fiscal policy, forest taxation and use of the funds, as well as on the institutional settings in place and the priorities chosen.

Economic considerations of sustainability are crucial for a post-transition [27] country. From an economic perspective, sustainable forestry can exist if the returns to it exceed those of alternative uses of the land and exceed the costs of forest management. In this way, sustainable forest management is embodied in sustained timber management $[27,97]$. However, from the previous political and economic system, Ukraine inherited mechanisms of decision-making which are not adjusted to market conditions for wood production and consumption. There is a lack of trained specialists in markets and entrepreneurships. There are insufficient financial and capital inputs to forestry.

The annexation of Crimea by Russia in 2014 and the war in Eastern Ukraine made the situation worse, both at the national level (e.g., with outflow of various types of capital), as well as the regional and local levels (e.g., as forestry considerations are not now central in 
these regions of Ukraine, while the environmental situation, for example, forest fires and land degradation in Eastern territories, is precarious) $[107,108]$. Under these conditions, and with inadequate institutions and acute market failures, it is impossible for Ukraine to operationalise an economic concept of sustainability in forestry, while in the context of this research, a pathway to sustainability lies through the development of markets and internalizing (where possible) the most important externalities.

Legislative and structural changes in forestry are needed, that is, those that will change the rules and plays of the game at all and across forestry levels c.f., [109]. We argue that economic considerations need to be enhanced within a context of a prevalence of public forestry (as in many other countries). However, the economic concerns must be wellsupported by social and environmental considerations, and sustainability in post-transition forestry must be operationalized concurrently in economic, social, and physical terms.

We agree with Nordberg (2007) that in Ukraine where, in general (except in Western areas), there is 'no living memory of market economy' it is particularly difficult to move forward, and that reaching a proper balance between State, businesses and the various public interests is crucial [87]. The idea of proper balancing is relevant to all post-transition countries including those with greater experience in markets. The evaluation of forest governance in Lithuania and Slovakia by Makrickiene et al. (2019) (using the criteria of efficiency, equity, transparency, participation and adaptiveness) provided evidence of a considerably more progress required 'toward adaptive governance characterized by flatter hierarchies, lighter regulatory load and greater decision autonomy' [110].

Lastly, concerning possible projections, post-transition forestry which is progressing towards sustainability would: (i) either entirely change social practices to establish novel governance arrangements; or (ii) continue interacting with the existing regimes to offer mixed governance arrangements (i.e., between the public and private sectors); or (iii) revisit historic social practices by offering them new dimensions c.f., [2,111]. The third scenario has its supporters in Ukraine c.f., [2], reflecting the views of many experts who are not convinced by a presentation of the expansion of markets as a consensual silver bullet for achieving sustainable forestry $[4,9]$.

\section{Conclusions}

The forestry case, analyzed in this paper, exemplifies the developments and plausible scenarios, from which other post-transition countries may learn. It illustrates how institutional reconfiguration in Ukrainian forestry has developed since the start of transition. It provides evidence that for the reconfiguration of social practices to be transformative (rather than adaptive) the changes introduced must challenge, alter and/or replace established institutions $[2,46,112]$ while guiding the development of the forest sector towards sustainability.

The theoretical novelty presented in this paper concerns adapting in the context of a post-transition country of the action arena concept of institutional changes. This conceptualization complements existing approaches to institutional changes, and is linked to civil society led forestry changes, and opportunities for and barriers to forestry being put on a sustainable pathway. The paper has shown that institutional reconfiguration can be motivated or triggered by challenges caused by institutional mismatches (e.g., between sustainability concerns and forestry institutions), and misfits or gaps (e.g., between policy goals and forestry practices; institutional environment and institutional arrangements). However, forestry sector actors commonly encounter difficulties in developing and scaling up new practices due to path dependent and interlinked governance systems.

We have shown that institutional interplays in this country manifest in 'path dependencies', rigidity and inertia. The findings demonstrate a specific context where robust but rigid institutions support each other by blocking changes towards sustainability, while novel civil society led arrangements are emerging to enable progressive changes [2]. Such changes would require the development of capabilities and raising of awareness of relevant stakeholders of a market economy and the problems to be faced while challenging the 
existing institutions, shifting existing power relations and creating new norms, rules, and decision-making arrangements.

In practical terms, we have found that the successful reconfiguration of social practices depends on supportive institutional conditions. In former transition countries (and in Ukraine, for approximately two decades), institutions were poorly framed, with characteristics of subjugating individual interests in favor of those of the State and of those in power [33]. We showed that a shadow economy is, to a large extent, caused by a mismatch between the pro-environmental regulation and financial incentives for forest practitioners to increase timber harvesting (driven by existing price systems, etc.), as well as by irrational financial flows and groundless taxation [73] (i.e., when "forest enterprises become 'cleaned out'", as reported by the experts interviewed). It is also caused by a poor economic situation and low salaries of foresters and decision-makers; impoverishment of forest-dependent communities; the lack of resources, including financial (at all levels of forest activity), and thus incapability of officials to monitor the cutting of timber and enforce compliance with sustainable forestry regulations.

Sustainable development [113] should reflect short and long-term societal interests and address the demands of present and future generations. To ensure sustainable and multifunctional development of post-transition forestry, significant benefits accrue from a reform of economic policy that increases the efficiency of timber supply. However, such changes in policy must be complemented by well-targeted measures to preserve forests, the state and quality of their natural assets, and their biodiversity and landscape values.

The role of government is crucial for balancing the economic objectives of forestry development with the social and environmental requirements. Governmental intervention, in terms of public environmental and social policies, is justified during the post-transition period. Over time, with institutional advances, direct government intervention gradually gives way to indirect guidance through policies designed to advance the role of markets. However, the role of government in regulating the tenure, management, financing, and production of public goods will still remain under the conditions of a well-functioning market economy.

Author Contributions: Conceptualization-M.N. and T.K.; methodology-M.N., T.K., A.N., M.M.; investigation-M.N., A.N., S.K., M.M.; data collection and interviewing-S.K., L.K., I.F., A.N., M.N.; analysis-M.N., A.N.; writing-original draft preparation-M.N.; commenting, reviewing, suggesting on improvement-T.K., S.S., C.B., D.M.; revising and editing M.N., D.M., C.B.; visualization and formatting-M.N., A.N., M.M., S.B.; supervision-M.N. All authors have read and agreed to the published version of the manuscript.

Funding: This project has received funding from the European Union's Horizon 2020 Research and Innovation Programme under Grant Agreement No. 677622, (SIMRA—Social Innovation in Marginalised Rural Areas) and GA 862448 (SHERPA). It was also partly funded by the Rural \& Environment Science \& Analytical Services Division of the Scottish Government through its Strategic Research Programme (2016-2021) and Research Grant Agency of the Slovak republic (Vega) for the project No.: 2/0170/21.

Institutional Review Board Statement: The work undertaken under the SIMRA project was conducted according to the guidelines of the Declaration of Helsinki, and approved by the Research Ethics Committee of James Hutton Institute, 7th August 2018.

Informed Consent Statement: Informed consent was obtained from all subjects involved in the study.

Data Availability Statement: The data presented in this study are available on request from the corresponding author. The data are not publicly available due to issues of respondent confidentiality and conditions of ethical approval.

Acknowledgments: The authors are grateful to the forestry experts interviewed for this paper for sharing their experience and knowledge, as well as to the reviewers of this paper. 
Conflicts of Interest: The authors declare no conflict of interest. The funders had no role in the design of the study; in the collection, analyses, or interpretation of data; in the writing of the manuscript, or in the decision to publish the results.

\section{References}

1. Daly, H.D. Sustainable Development: Definitions, Principles, Policies; School of Public Affairs University of Maryland: College Park, MD, USA, 2002.

2. Nijnik, M.; Kluvankova, T.; Nijnik, A.; Kopiy, S.; Melnykovych, M.; Sarkki, S.; Barlagne, C.; Brnkalakova, S.; Kopiy, L.; Fizyk, I.; et al. Is there a scope for social innovation in Ukrainian forestry? Sustainability 2020, 12, 9674. [CrossRef]

3. United Nations Organization. Transforming Our World: The 2030 Agenda for Sustainable Development; United Nations Organization: New York, NY, USA, 2015.

4. Nijnik, M. To Sustainability in Ukraine's Forestry; Wageningen University Press: Wageningen, The Netherlands, 2002; 156p.

5. Rice, R.E.; Gullison, R.E.; Reid, J.W. Can sustainable management save tropical forests? Sci. Am. 1997, 276, 382-386. [CrossRef]

6. European Commission. Communication on the Implementation of the EU Forestry Strategy, COM (2005) 84 Final SEC (2005) 333; European Commission: Brussels, Belgium, 2005.

7. Palahí, M.; Hetemäki, L.; Potočnik, J. Bioeconomy: The Missing Link to Connect the Dots in the EU Green Deal. 2020. Available online: https://blog.efi.int/bioeconomy-the-missing-link-to-connect-the-dots-in-the-eu-green-deal/ (accessed on 6 February 2021).

8. McHale, J. Eastern European Studies: Economics. In International Encyclopedia of the Social \& Behavioral Sciences, 1st ed.; Smelser, N.J., Baltes, P.B., Eds.; Pergamon Elsevier Ltd.: Oxford, UK, 2001; pp. 3984-3990.

9. Nijnik, M.; Bizikova, L. The European Union Sustainable Forest Management and Climate Change Mitigation Policies from a Transition Country's Perspective. In Sustainable Forestry in Theory and Practice; Reynolds, K.M., Thomson, A.J., Shannon, M.A., Köhl, M., Ray, D., Rennolls, K., Eds.; CAB International: Wallingford, UK, 2007; pp. 56-74.

10. World Bank. Ukraine Country Forest Note; World Bank: Washington, DC, USA, 2020; 72p.

11. BRDO (Better Regulation Delivery Office). The Budget of Ukraine Loses 200 Million Hryvnas Annually Because of Illegal Sawmills', Better Regulation Delivery Office Press Release. 2017. Available online: http://en.brdo.com.ua/main/brdo-budgetukraine-loses-200-million-hryvnasannually-illegal-sawmills / (accessed on 6 February 2021).

12. Chernyavskyy, M.; Soloviy, I.; Henyk, Y.; Kaspruk, O.; Henyk, O.; Melnykovych, M.; Herasym, H.; Savka, V. Problems of Legal Assess of Local Population to Forest Resources and Illegal Logging in Forests of the Carpathians and the Western Polissya; Liga Press: Lviv, Ukraine, 2011; p. 450.

13. Krott, M. Forest government and forest governance within a Europe in change. In The Multifunctional Role of Forests-Policies, Methods and Case Studies; Cesaro, L., Gatto, P., Pettenella, D., Eds.; EFI Proc. No. 55; Gummerus Printing: Saarijärvi, Finland, 2008; pp. 13-25.

14. Bizikova, L.; Nijnik, M.; Kluvanková-Oravská, T. Sustaining multifunctional forestry through the developing of social capital and promoting participation: A case of multiethnic mountain communities. Small Scale For. 2012, 301-319. [CrossRef]

15. Nijnik, M.; Secco, L.; Miller, D.; Melnykovych, M. Can social innovation make a difference to forest-dependent communities? For. Policy Econ. 2019, 100, 207-213. [CrossRef]

16. Krynytskyy, H.; Chernyavskyy, M.; Krynytska, O. Forestry in Ukraine: Current state and development trends. Bull. Transilvania Univ. Braşov. Ser. II For. Wood Ind. Agric. Food Eng. 2016, 9, 25-30.

17. State Forest Resource Agency of Ukraine. General Characteristics of Ukraine's Forest. 2020. Available online: http://dklg.kmu. gov.ua/forest/control/uk/publish/article?art_id=62921\& (accessed on 6 February 2021).

18. ENPI-FLEG. FLEG Program in the Forest Sector of Ukraine: Achievements and Challenges for the Future (World Bank Activities). 2017. Available online: http://www.enpi-fleg.org/site/assets/files/2130/fleg_program_in_the_forest-sector-of-ukraine.pdf (accessed on 6 February 2021).

19. The Forest Code of Ukraine. Kyiv. 2006. Available online: http://zakon.rada.gov.ua/cgi-bin/laws/anot.cgi?nreg=3852-12 (accessed on 6 February 2021).

20. State Forest Resource Agency of Ukraine. Strategy for Sustainable Development and Institutional Reform of the Forestry and Wildlife Management in Ukraine for the Period up to 2022; State Forest Resource Agency of Ukraine: Kyiv, Ukraine, 2017.

21. Law of Ukraine "On the Basic Ambush (Strategy) of the State Ecological Policy of Ukraine for the Period until 2030", No. 2697-VIII Signed on 28 February 2019. Available online: https:/ /ips.ligazakon.net/document/view/t192697?an=1 (accessed on 6 February 2021).

22. Land Reform Strategy in Ukraine until 2024. 2020. Available online: https://voxukraine.org/en/land-reform-strategy-inukraine-until-2020/ (accessed on 6 February 2021).

23. Law of Ukraine "On Amendments to the Law of Ukraine On Peculiarities of State Regulation of Activities of Entrepreneurial Activities Related to the Sale and Export of Timber (Concerning the Moratorium on the Export of Timber and Lumber in Raw Form)", No. 325-VIII Signed on 7 July 2015. Available online: https:/ / zakon.rada.gov.ua/ (accessed on 10 April 2021).

24. Law of Ukraine "On Amendments to the Forest Code of Ukraine Regarding the National Forest Inventory", No. 643-IX Signed on 23 July 2020. Available online: https:/ / zakon.rada.gov.ua/ (accessed on 10 April 2021). 
25. Soloviy, I.; Cubbage, F. Forest Policy in Aroused Society: Ukrainian Post-Orange Revolution Challenges. For. Policy Econ. 2007, 10, 60-69. [CrossRef]

26. Gensiruk, S. Ax is roaming in the Carpathians. Rural News, 1 November 1999. (In Ukrainian)

27. Nijnik, M. To an Economist's Perception on Sustainability in Forestry-in-Transition. For Policy Econ. 2004, 6, 403-413. Available online: http://www.sciencedirect.com/science/article/pii/S1389-9341(04)00040-1 (accessed on 8 April 2021). [CrossRef]

28. WWF. Report “On Sanitary Logging in Ukraine”. 2018. Available online: https://www.wwf.de/fileadmin/fm-wwf/ Publikationen-PDF/WWF-Report-Sanitary-logging-Ukraine.pdf (accessed on 6 February 2021).

29. FSC. Forest Stewardship Council in Ukraine Facts and Figures. 2019. Available online: https://ua.fsc.org/ua-ua/nasha-diyalnist/ facts_and_figures (accessed on 6 February 2021).

30. La Porta, R.; Lope-de-Silanes, F.; Shleifer, A.; Vishny, R. Trust in Large Organisations. Am. Econ. Rev. 1997, 87, 333-338.

31. Shleifer, A.; Vishny, R. The Grabbing Hand: Government Pathologies and Their Cures; Harvard University Press: Cambridge, MA, USA, 1998.

32. Bromley, D.W. Economic institutions and governance of the commons. In Environment, Inequality, and Collective Action; Basili, M., Franzini, M., Vercelli, A., Eds.; Routledge: London, UK, 2006.

33. Nijnik, M.; Oskam, A. Governance in Ukrainian Forestry: Trends, Impacts and Remedies. Agric. Resour. Gov. Ecol. 2004, 3, 116-133. [CrossRef]

34. Kluvankova, T.; Chobotová, V.; Banaszak, I.; Slaviková, L.; Trifunovova, S. From Government to Governance for Biodiversity: The perspective of CEE Transition countries. Environ. Policy Gov. 2009, 19, 186-196. [CrossRef]

35. Baker, S. Environmental Governance and EU Enlargement: Developments in New Member States, the Western Balkans and the Near Neighbours. In Central and South Eastern Europe; Gladman, I., Ed.; Routledge: London, UK, 2008.

36. Vatn, A. Rationality, institutions and environmental policy. Ecol. Econ. 2005, 55, 203-217. [CrossRef]

37. Ostrom, E. Governing the Commons; Cambridge University Press: New York, NY, USA, 1990.

38. North, D. Institutes and Credible Commitment. J. Inst. Econ. 1993, 149, 11-23.

39. North, D. The Contribution of the New Institutional Economics to an Understanding of Transition Problems; UNU/WIDER 97 Annual Lecture; The United Nations University World Institute for Development Economics Research: Helsinki, Finland, 1997.

40. Sabatier, P. The Advocacy Coalition Framework: Revisions and Relevance for Europe. J. Eur. Public Policy 1998, 5, 98-130. [CrossRef]

41. Coase, R.H. The Nature of the Firm. Econ. New Ser. 1937, 4, 386-405. Available online: http:/ /links.jstor.org/sici?sici=0013-0427\% 28193711\%292\%3A4\%3A16\%3C386\%3ATNOTF\%3E2.0.CO\%3B2-B (accessed on 10 April 2021). [CrossRef]

42. Kluvánková, T.; Gežík, V. Survival of commons? Institutions for robust forest social-Ecological systems. J. For. Econ. 2016, 22, 175-185.

43. Williamson, O. Transaction-cost economics: The governance of contractual relations. In Organizational Economics; Barney, J., Ouchi, W., Eds.; Jossey-Bass Publishers: San Francisco, CA, USA, 1986; pp. 98-129.

44. Ostrom, E. A general framework for analyzing sustainability of social-ecological systems. Science 2009, 325, 419-422. [CrossRef]

45. Kluvankova, T.; Gezik, V.; Spacek, M.; Brnkalakova, S.; Slee, B.; Polman, N.; Valero, D.; Bryce, R.; Alkhaled, S.; Secco, L.; et al. Deliverable 2.2. Transdisciplinary Understanding of Social Innovation in Marginalised Rural Areas. SIMRA. 2017. Available online: http:/ / www.simra-h2020.eu/wp-content/uploads/2017/10/SIMRA_D2_2_Transdisciplinary-_understanding_of_SI_ in_MRAs.pdf (accessed on 6 February 2021).

46. Kluvankova, T.; Nijnik, M.; Spacek, M.; Sarkki, S.; Lukesch, R.; Perlik, M.; Melnykovych, M.; Valero, D.; Brnkalakova, S. Social innovation for sustainability transformation and its diverging development paths in marginalised rural areas. Sociol. Rural. 2021. [CrossRef]

47. North, D. Institutions, Institutional Change and Economic Performance; Cambridge University Press: Cambridge, UK, 1990.

48. Méndez, P.F.; Amezaga, J.M.; Santamaría, L. Explaining path-dependent rigidity traps: Increasing returns, power, discourses, and entrepreneurship intertwined in social-ecological systems. Ecol. Soc. 2019, 24, 30. [CrossRef]

49. Diani, M. The concept of social movement. Sociol. Rev. 1992, 40, 1-25. [CrossRef]

50. Sarkki, S.; Parpan, T.; Melnykovych, M.; Zahvoyska, L.; Voloshyna, N.; Derbal, J.; Nijnik, M. Beyond participation! Socialecological innovations facilitating movement from technocratic state to collaborative landscape governance in Ukraine. Landsc. Ecol. 2019, 34, 1601-1618. [CrossRef]

51. Knight, J. Institutions and Social Conflict; Cambridge University Press: Cambridge, UK, 1992.

52. Ostrom, E. Polycentric systems for coping with collective action and global environmental change. Glob. Environ. Chang. 2010, 20, 550-557. [CrossRef]

53. Scott, W.R. Institutions and Organizations: Ideas, Interests and Identities; Sage Publs: Thousand Oaks, CA, USA, 1995; 360p.

54. Hodgson, G.M. The Evolution of Institutional Economics: Agency, Structure, and Darwinism in American Institutionalism; Routledge: London, UK; New York, NY, USA, 2004.

55. Crawford, E.S.; Ostrom, E. A Grammar of Institutions. Am. Political Sci. Rev. 1995, 89, 582-600. [CrossRef]

56. Young, O.R. The Institutional Dimensions of Environmental Change: Fit, Interplay and Scale; MIT Press: Cambridge, UK, 2002.

57. Secco, L.; Pisani, E.; Da Re, R.; Rogelja, T.; Burlando, C.; Vicentini, K.; Pettenella, D.; Masiero, M.; Miller, D.; Nijnik, M. Towards a method of evaluating social innovation in forest-dependent rural communities: First suggestions from a science-stakeholder collaboration. For. Policy Econ. 2019, 104, 9-22. [CrossRef] 
58. Gerrard, C. Ten Institutional Perspectives on Agriculture and Rural Development: A Conceptual Framework for Policy Makers. Managers and Analysts. In Proceedings of the XXIV IAAE Conference Proceedings, Berlin, Germany, 13-18 August 2000; pp. 1-11.

59. Eggertsson, T. The Economics of Institutions in Transition Economies. In Institutional Change and the Public Sector in Transitional Economies, Discussion Paper 241; Shiavo-Campo, S., Ed.; World Bank: Washington, DC, USA, 1994; pp. 19-50.

60. Nijnik, M.; Nijnik, A.; Sarkki, S.; Muñoz-Rojas, J.; Miller, D.; Kopiy, S. Is forest related decision-making in European treeline areas socially innovative? A Q-methodology enquiry into the perspectives of international experts. For. Policy Econ. 2018, 92, 210-219. [CrossRef]

61. Sarkki, S.; Ficko, A.; Miller, D.; Barlagne, C.; Melnykovych, M.; Jokinen, M.; Soloviy, I.; Nijnik, M. Human values as catalysts and consequences of social innovations. For. Policy Econ. 2019, 33-44. [CrossRef]

62. Rotmans, J.; Loorbach, D. Complexity and Transition Management. Ind. Ecol. 2009, 13, 184-196. [CrossRef]

63. Matthies, A.-L.; Stamm, I.; Hirvilammi, T.; Närhi, K. Ecosocial Innovations and Their Capacity to Integrate Ecological, Economic and Social Sustainability Transition. Sustainability 2019, 11, 2107. [CrossRef]

64. Vercher, N.; Barlagne, C.; Hewitt, R.; Nijnik, M.; Esparcia, J. Narratives of social innovation. A comparative analysis of community-led initiatives in Scotland and Spain. Sociol. Rural 2021, 61, 163-189. [CrossRef]

65. Cohen, W.; Levinthal, D. Absorptive Capacity: A New Perspective on Learning and Innovation. Adm. Sci. Q. 1990, 35, 128-152. [CrossRef]

66. Kluvánková-Oravská, T.; Chobotová, V. Shifting governance. Managing the commons: The case of Slovensky Raj National Park. Sociologia 2006, 38, 221-244.

67. Kluvankova, T.; Brnkaláková, S.; Špaček, M.; Slee, B.; Nijnik, M.; Valero, D.; Miller, D.; Bryce, R.; Kozová, M.; Polman, N.; et al. Understanding social innovation for the well-being of forest-dependent communities: A preliminary theoretical framework. For. Policy Econ. 2018, 97, 163-174. [CrossRef]

68. Moore, M.-L.; Tjornbo, O.; Enfors, E.; Knapp, C.; Hodbod, J.; Baggio, J.A.; Norström, A.; Olsson, P.; Biggs, D. Studying the complexity of change: Toward an analytical framework for understanding deliberate social-ecological transformations. Ecol. Soc. 2014, 19, 54. [CrossRef]

69. Loorbach, D.; Wittmayer, J.; Avelino, F.; von Wirth, T.; Frantzeskaki, N. Transformative innovation and translocal diffusion. Env. Innov. Soc. Trans. 2020, 35, 251-260. [CrossRef]

70. Aghaei Chadegani, A.; Salehi, H.; Yunus, M.M.; Farhadi, H.; Fooladi, M.; Farhadi, M.; Ebrahim, N.A. A comparison between two main academic literature collections: Web of science and Scopus databases. Asian Soc. Sci. 2013, 9, 18-26. [CrossRef]

71. Ranacher, L.; Sedmik, A.; Schwarzbauer, P. Public perceptions of forestry and the forest-based bioeconomy in the European Union. In EFI Knowledge to Action; European Forest Institute: Joensuu, Finland, 2020. [CrossRef]

72. Komendar, V. The state committee of wiping out forests? Rural News, 22 May 2001. Kiev, Ukraine. (In Ukrainian)

73. Bolokhovets, Y. Forest Tax System Need to Be an Instrument to Stimulate the Development. Ukrainians in World, 6 June 2021. Available online: https:/ / www.uainworld.com/yurij-bolohovecz-podatok-maye-buty-instrumentom-stymulyuvannya-ta-rozvytku/ ?fbclid=IwAR0HZmtTgek_KZ9nGY56JL0NF3MOaxASs2ZTFm_vRiRc6_mEp9VCI8HFyTA(accessed on 15 February 2021).

74. Law of Ukraine "On Elements of the State Regulation of Business Operators' Activities Related to the Sale and Export of Timber". No. 2860-IV Signed on 8 September 2005. Available online: https:/ / zakon.rada.gov.ua/ (accessed on 10 April 2021).

75. Kyslytska, A. Why Ukrainian Forests Don't Benefit from the Ban on Wood Export-Interview. 2018. Available online: https://ukraineworld.org/articles/reforms/why-ukrainian-forests-dont-benefit-ban-wood-export-interview (accessed on 15 February 2021).

76. Major Groups. Major Groups-Led Initiative in Support of the United Nations Forum on Forests. Forests and Economic Development: Crafting the Path for Forests to Contribute to Sustainable Development; Okrah, L., Broughton, L., Eds.; Report of Workshop Proceedings Compiled; United Nations Forum on Forests: Rio de Janeiro, Brazil, 2013; pp. 36-42.

77. ENPI-FLEG II. Governance of Local Forests in East Countries and Russia; IUCN: Gland, Switzerland, 2016; 318p.

78. Melnykovych, M.; Nijnik, M.; Soloviy, I.; Nijnik, A.; Sarkki, S.; Bihun, Y. Social-ecological innovation in remote mountain areas: Adaptive responses of forest-dependent communities to the challenges of a changing world. Sci. Total Environ. 2018, 613, 894-906. [CrossRef]

79. Henyk, Y.; Henyk, O.; Melnykovych, M. Threats to stability and sustainability of forests in the Carpathians and reasons for law violations in the forest sector in the Carpathian region of Ukraine. For. Timber Pap. Wood Ind. Int. Sci. Technol. Collect. Lviv UNFU 2012, 38, 29-34.

80. Earthsight. Flatpacked Forests. 2020. 52p. Available online: https://www.earthsight.org.uk/investigations/flatpacked-forests (accessed on 6 February 2021).

81. Law of Ukraine "On Certain Measures for the Conservation of Forests and the Rational Use of Forest Resources". No. 511/2019. Available online: https:/ / www.president.gov.ua/documents/5112019-28301 (accessed on 6 February 2021).

82. van Kooten, G.C.; Binkley, C.S.; Delcourt, G. Effect of carbon taxes and subsidies on optimal forest rotation age and supply of carbon services. Am. J. Agric. Econ. 1995, 77, 365-374. [CrossRef]

83. Earthsight. Complicit in Corruption: How Billion-Dollar Firms and EU Governments Are Failing Ukraine's Forests. 2018. Available online: https://www.earthsight.org.uk/news/investigations/complicit-in-corruption-report (accessed on 10 April 2021). 
84. Keeton, W.S.; Angelstam, P.M.; Baumflek, Y.; Bihun, M.; Chernyavskyy, S.M.; Crow, A.; Deyneka, M.; Elbakidze, J.; Farley, V.; Kovalyshyn, B.; et al. Sustainable forest management alternatives for the Carpathian Mountain region, with a focus on Ukraine. In The Carpathians: Integrating Nature and Society Towards Sustainability; Kozak, J., Ostapowicz, K., Bytnerowicz, A., Wyzga, B., Eds.; Springer: Berlin/Heidelberg, Germany, 2013; pp. 331-352.

85. Krott, M.; Tikkanen, I.; Petrov, A.; Tunytsya, Y. Policies of Sustainable Forestry in Belarus, Russia and Ukraine; EFI Research Report; Brill: Leiden, The Netherlands; Boston, MA, USA; Koln, Germany, 2000; p. 9.

86. Timber Industry. EU Requests Arbitration with Ukraine on Wood Export Ban. 2019. Available online: https://www. timberindustrynews.com/eu-requests-arbitration-ukraine-wood-export-ban/ (accessed on 6 February 2021).

87. Nordberg, M. Ukraine reforms in forestry 1990-2000. For. Policy Econ. 2007, 9, 713-729. [CrossRef]

88. Soloviy, I.; Nijnik, M.; Deyneka, A.M.; Melnykovych, M. Reimagining forest policy, institutions and instruments through concepts of ecosystem services and social innovation: Ukraine in the focus. Sci. Bull. UNFU 2017, 27, 82-87. [CrossRef]

89. Law of Ukraine "On Additional Actions Regarding the Development of the Forest Sector, Rational Nature Management and Preservation of the Nature Protection Fund Objects". No. 381/2017, Signed on 21 November 2017. Available online: https:/ / zakon.rada.gov.ua/ (accessed on 10 April 2021).

90. State Strategy on Forest Governance for the Period until 2035. Draft under Public Discussion. 2020, p. 34. Available online: https:/ / tlu.kiev.ua/uploads/media/Proekt_Strategii__2035_07.10.20__1_.pdf (accessed on 10 April 2021).

91. Jensen, D.N. Patriomonialism in Post-Soviet Russia. RFEIRL Newsline, 17 July 1997.

92. Von Hirschhausen, C. Industrial Restructuring in Ukraine Seven Years after Independence: From Socialism to a Planning Economy? Communist Econ. Econ. Transform. 1998, 10, 451-465.

93. Soloviy, I.; Dushna-Melnykovych, M. Analysis of Forestry Professionals' Attitudes towards SFM Paradigm Implementation. In Ecological Economics and Sustainable Forest Management: Developing a Transdisciplinary Approach for the Carpathian Mountains; Soloviy, I., Keeton, W., Eds.; UNFU Press, Liga-Press: Lviv, Ukraine, 2009; pp. 348-368. (In Ukrainian)

94. Melnykovych, M.; Soloviy, I. Contribution of forestry to the well-being of mountain forest dependent communities' in the Ukrainian Carpathians. J. Proc. For. Acad. Sci. Ukr. Coll. Sci. Pap. 2014, 12, 233-241.

95. Synyakevych, I.; Soloviy, I.; Deyneka, A. Forest sector of Ukraine in the 21st century: State of art, scenarios, and policy for sustainable development. In Ecological Economics and Sustainable Forest Management: Developing a Transdisciplinary Approach for the Carpathian Mountains; Soloviy, I., Keeton, W.S., Eds.; UNFU Press, Liga-Press: Lviv, Ukraine, 2009; pp. 127-150. (In Ukrainian)

96. Dynka, P.K. Reforming Forestry of Ukraine in the Context of the Development of Civil Society. Sci. Bull. UNFU 2017, 27, 9-13. [CrossRef]

97. Nijnik, M.; Van Kooten, G.C. Forestry in the Ukraine: The Road Ahead? For. Policy Econ. 2000, 1, 139-153. [CrossRef]

98. Elbakidze, M.; Angelstam, P. Sustainable forest management from policy to landscape and back again: A case study in the Ukrainian Carpathians Mountains. In The Carpathians: Integrated Nature and Society towards Sustainability; Kozak, J., Ostapowicz, K., Bytnerowicz, A., Wyzga, B., Eds.; Springer: Berlin, Germany, 2013.

99. Metzger, M.; Dick, J.; Gardner, A.; Bellamy, C.; Blackstock, K.; Brown, C.; Chisholm, R.; Cochrane, P.; Drewitt, J.; Gimona, A.; et al. Knowledge sharing, problem solving and professional development in a Scottish Ecosystem Services Community of Practice. Reg. Environ. Chang. 2019, 19, 2275-2286. [CrossRef]

100. Martiskainen, M. The role of community leadership in the development of grassroots innovations. Env. Innov. Soc. Trans. 2017, 22, 78-89. [CrossRef]

101. Carlsson, L.; Lungren, N.-G.; Olsson, M.; Varankin, M. Institutions and Emergence of Markets—Transition in the Arkhangelsk Forest Sector. Interim Report; IR-99-021; IIASA: Laxenburg, Austria, 1999.

102. Zahvoyska, L.; Nijnik, M.; Sarkki, S.; Nijnik, A.; Pelyuch, O. Insights into treeline ecosystem services of the Ukrainian Carpathians from a stakeholders' perspective: An analysis of challenges for adaptive governance. J. Proc. For. Acad. Sci. Ukr. Coll. Sci. Pap. 2015, 13, 193-200.

103. Buksha, I. Forest Sector in Transition to Market Economy. In Proceeding of the UNESE/FAO 6th Meeting of the Team of Specialists on Countries in Transition, Warsaw, Poland, 3-6 March 2004. Available online: https://www.unece.org/fileadmin/DAM/ timber/h3/Warsaw\%20doc/Documents/Ukraine.doc (accessed on 10 April 2021).

104. Sarkki, S.; Ficko, A.; Grunewald, K.; Kyriazopoulos, A.; Nijnik, M. How pragmatism in environmental science and policy can undermine sustainability transformations: The case of marginalized mountain areas under climate and land use change. Sustain. Sci. 2016, 12, 549-561. [CrossRef]

105. Vatn, A.; Vedeld, P. Fit, interplay, and scale: A diagnosis. Ecol. Soc. 2012, 17, 12. [CrossRef]

106. Beunen, R.; Patterson, J.J. Analysing institutional change in environmental governance: Exploring the concept of 'institutional work'. J. Environ. Plan. Manag. 2019, 62, 12-29. [CrossRef]

107. Mykhnenko, V. Causes and Consequences of the War in Eastern Ukraine: An Economic Geography Perspective. Eur. Asia Stud. 2020, 72, 528-560. [CrossRef]

108. Duprey, B.; Bondarenko, O. Assessing Environmental Impacts of Armed Conflict: The Case of Eastern Ukraine; The Truth Hounds and the National Endowment for Democracy Report; Truth Hounds: Kyiv, Ukraine, 2019. Available online: https://deis.menr.gov.ua/ lib/files/Ecology_crimes_TruthHounds.pdf (accessed on 5 April 2021). 
109. Dubovichi, I.; Lesiuk, H.; Soloviy, I.; Soloviy, V. Long Way from Government to Governance: Meta-Analysis of Ukrainian Forestry Reformation. In Proceedings of the International Symposium Forest and Sustainable Development, Brașov, Romania, 25-27 October 2018. Available online: https:/ / silvic.unitbv.ro/images/conferinte/fsd/proceedings/12.-Dubovich---ID-175.pdf (accessed on 6 February 2021).

110. Makrickiene, E.; Brukas, V.; Brodrechtova, Y.; Mozgeris, G.; Sedmák, R.; Šálka, J. From command-and-control to good forest governance: A critical interpretive analysis of Lithuania and Slovakia. For. Policy Econ. 2019, 109, 102024. [CrossRef]

111. Pel, B.; Kemp, R. Between innovation and restoration; towards a critical-historicizing understanding of social innovation niches. Technol. Anal. Strateg. Manag. 2020, 32, 1182-1194. [CrossRef]

112. Haxeltine, A.; Avelino, F.; Pel, B.; Dumitru, A.; Kemp, R.; Longhurst, N.C.; Wittmayer, J.; MacCallum, D. A Framework for Transformative Social Innovation: TRANSIT Working Paper \#5; TRANsformative Social Innovation Theory (TRANSIT), 2016. Available online: http:/ / www.transitsocialinnovation.eu/resource-hub/a-framework-for-transformative-social-innovationtransit-working-paper-5 (accessed on 10 April 2021).

113. Couto, E.V.d.; Oliveira, P.B.; Vieira, L.M.; Schmitz, M.H.; Ferreira, J.H.D. Integrating Environmental, Geographical and Social Data to Assess Sustainability in Hydrographic Basins: The ESI Approach. Sustainability 2020, 12, 3057. [CrossRef] 